
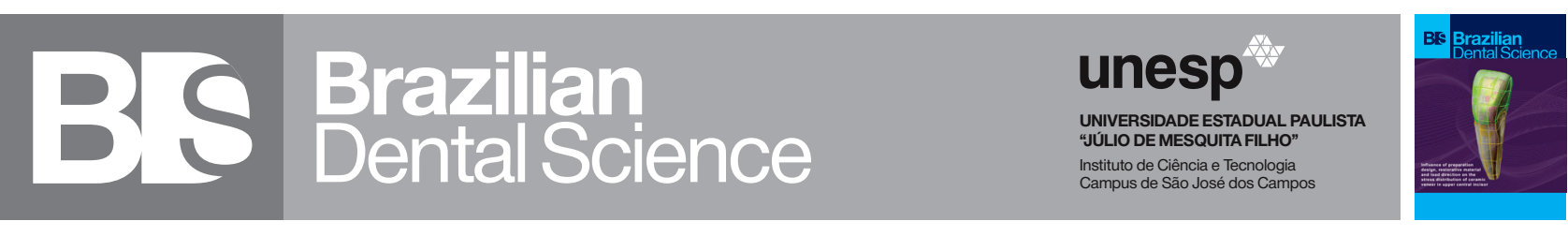

\title{
Awareness of antibiotic use and antibiotic resistance amongst dental students
}

\author{
Conscientização sobre uso e resistência à antibióticos entre estudantes de odontologia \\ Khaloud TARIQ ${ }^{1}$, Muhammad HASSAN ${ }^{2}$, Mehreen WAJAHAT ${ }^{3}$, Nadia MUNEER $^{3}$, Eisha IMRAN ${ }^{4}$ \\ 1 - Department of Community Dentistry, University of Lahore, Lahore, Pakistan. \\ 2 - Department of Dental Materials, University of Lahore, Lahore, Pakistan. \\ 3 - Department of Dental Materials, Avicenna Dental College, Lahore, Pakistan. \\ 4 - Department of Dental Materials, Islamic International Dental College, Riphah International University, Islamabad, Pakistan.
}

\begin{abstract}
Objective: Antibiotic resistance is one of the most threatening public health problems of $20^{\text {th }}$ century. Along with physicians, dental practitioners also routinely prescribe medications for oral and dental infections. However, previous studies have shown that dental surgeons often prescribe antibiotics where new evidence have suggested other treatment measures. Since students in their clinical year prescribe antibiotics under supervision, it is important to understand if they are aware of severity of antibiotic resistance and its impact. Hence, the study aimed to assess awareness of antibiotic use and resistance amongst dental students. Material and Methods: Cross-sectional survey was conducted amongst $3^{\text {rd }}$ and $4^{\text {th }}$ year dental students of 4 colleges of Pakistan. A validated questionnaire was adopted from WHO and PHE (Public Health England). It included true or false and Likert scale questions relating to knowledge and attitude of antibiotic use and antibiotic resistance. Results: Out of 396 responses, majority students were not aware of the terms superbugs (69.7\%) and AMR (79\%). 89.6\% thought that humans can become resistant to antibiotics. $88.6 \%$ agreed that antibiotic resistance is a major threat. $61.4 \%$ thought they couldn't do much to stop antibiotic resistance. $87.6 \%$ agreed that doctors should only prescribe antibiotics when needed. Conclusion: Overall dental students were aware of antibiotic use and importance of antibiotic resistance although their knowledge associated with antibiotic resistance was not satisfactory. It is vital that students must be taught about mechanism of antibiotic resistance and good prescription practices.
\end{abstract}

\section{KEYWORDS}

Antibiotic resistance; Knowledge; Attitude; Dental students.

\section{RESUMO}

Objetivo: A resistência antibiótica é um dos problemas de saúde pública mais ameaçadores do século 20. Assim como os médicos, os profissionais de odontologia também prescrevem rotineiramente medicamentos para infecções bucais e dentárias. No entanto, estudos prévios apontam que cirurgiões-dentistas prescrevem antibióticos para casos nos quais, as mais recentes evidências, indicam outros tipos de intervenção. Considerando que os estudantes prescrevem antibióticos durante estágios clínicos, sob supervisão, torna-se pertinente averiguar se os mesmos estão cientes da severidade da resistência antibiótica e as suas implicações. Assim, o objetivo deste estudo foi investigar o grau de conscientização quanto ao uso e a resistancia antibiótica entre os estudantes de odontologia. Material e Métodos: Pesquisa transversal foi conduzida entre os estudantes do 30 e 40 ano em 4 universidades do Paquistão. Foram utilizados questionários validados pela Organização mundial de Saúde e Saúde pública da Inglaterra. Estes incluíram perguntas de verdadeiro ou falso e escala relacionadas ao conhecimento e aplicação de antibióticos e resistência à estes. Resultados: Dentre as 396 respostas, a maioria dos estudantes não conhecia o termo superbactéria (69.7\%) e AMR (79\%). 89,6\% pensaram que humanos podem se tornar resistentes à antibióticos. 88,6\% concordaram que a resistência à antibióticos é uma grande ameaça. $61,4 \%$ pensaram que eles não havia muito o que eles pudessem fazer para combater a resistência antibiótica. 87.,6\% concordaram que médicos devem prescrever antibióticos apenas quando estritamente necessário. Conclusão: No geral, estudantes de Odontologia estão cientes do uso de antibióticos e a importância da resistência antimicrobiana embora o seu conhecimento a cerca do assunto não seja satisfatório. É vital que os estudantes sejam orientados sobre os mecanismos de resistência antibiótica e as práticas adequadas de prescrição desses medicamentos.

\section{PALAVRAS-CHAVE}

Resistência antibiótica; Conhecimento; Atitude; Estudantes de odontologia. 


\section{INTRODUCTION}

A ntibiotics proved to be nothing short of a "miracle drug" in an era when deaths due to bacterial infections were on the rise. However, with passage of time, practitioners started misusing the prescription of antibiotics even to the patients whose condition may have improved otherwise. Inappropriate and overuse of antibiotics led to bacteria undergoing mutation. This mutation gave rise to antibiotic resistance, which is defined as the capacity of a bacteria to withstand the impact of an antibiotic [1]. Antibiotic Resistance is ascending to abnormal level in all parts of the world despite widespread warnings about unwarranted use of antibiotics by notably by Centers for Disease Control and Prevention (CDC) and World Health Organization (WHO) [2]. Inept antibiotics usage caused this phenomenon to spread rapidly that it endangers lives of more than million people around the globe. About 33,110 deaths occurred due to resistant bacterial strains in Europe with numbers having amplified by now [3]. In Asia, antibiotic consumption increased exponentially in India, peaking at $79 \%$ in China and by $65 \%$ in Pakistan [4].

Till now, most bacteria have demonstrated the ability to withstand the effect of antibiotics thus, compromising our capacity to treat common ailments. This not only results in absence from school or work, but also associated with increased economic burden.

Oral cavity contains many bacteria which are part of both commensals and pathogens [5]. Coupled with factors such as improper nutrition and oral hygiene habits, these bacteria; especially pathogenic; cause infections such as gingivitis, periodontitis and caries. These infections can further aggravate into serious illnesses if left untreated [5]. Their treatment usually entails improving eating habits and oral hygiene along with eliminating causal organisms through scaling, root planning, filling or root canal treatment. These conditions seldom require oral antibiotic prescription unless the infection spreads to other tissues or becomes chronic.
Dental students in their clinical years are taught about common analgesics and antibiotics which can be prescribed for oral infections and associated pain. However, curriculum has not been revised considerably to acquaint them with latest recommendations. For example, metronidazole and amoxicillin are sometimes prescribed in case of generalized gingivitis, periodontitis and periapical infection [6]. However, several studies have also shown that students' compliance with antibiotic prescription guidelines are not satisfactory [7-9]. A study conducted amongst Saudi students depicted unnecessary antibiotic prescription by them for conditions which did not call for prescription This could mean that they are not adequately aware of repercussions of inappropriate antibiotic prescription [7]. Hence, it is important to understand the level of knowledge and attitude of students in clinical years so that they can be educated about any misinformed concepts.

Dental associations of UK, US, and Canada among others, have published guidelines for use of antibiotic and focuses on cases where antibiotic prescription is vital to resolve infection that cannot be treated alone by procedures [10]. Such standards have yet to be introduced in Pakistan. This absence of guideline results in blatant prescription of antibiotics, that could potentially contribute to resistance [11]. Through this study, the researchers aim to investigate awareness of antibiotic resistance among dental students who are in their clinical years, which can possibly help in foreseeing their future prescription practices. The results will help in determining if additional steps need to be taken to educate students about and possibly introduce the concept of antibiotic stewardship amongst teachers so as to ensure safe practices.

\section{METHODOLOGY}

It was a cross sectional study conducted in 4 dental institutes namely University College of Dentistry (UCD), Sharif Medical and Dental College (SMDC), Combined Military Hospital (CMH) Medical College and Institute of Dentistry and Margalla Institute of Health Sciences (MIHS). 
Dental students of 3rd and 4th year participated in this study conducted from May-September 2019. Sample size was calculated using cochran's formula with sample population of approximately 5000 students who are in their 3rd and final year of study in registered dental colleges of Pakistan. With margin of error at 5\% and confidence level 95\%, sample size was estimated at 370. A structured questionnaire was adapted from prevalidated survey of Public Health England (PHE) and WHO [12,13], and used after conducting a pilot study amongst 25 participants where no issues were reported regarding understanding of questionnaire. Reliability was tested with Cronbach alpha value of 0.74 , which is considered adequate. Ethical approval from the ethical review board (ERB) of UCD was sought prior to this. A 26-item questionnaire was finalized which had questions related to knowledge of terms, importance of antibiotic use and impact of resistance perceived. It was hand distributed amongst students through non-random sampling by two investigators. Response options of "true', "false" and "don't know" were used in questions relating to knowledge. They have been dichotomized into "sufficient knowledge" for "true" and "insufficient knowledge" for "false" and "don't know" respectively. A 5-point Likert scale was incorporated in this survey to assess the attitude of students regarding antibiotic use and antibiotic resistance. The options of "strongly agree" "agree", "strongly disagree" "disagree" and "nor agree neither disagree" are grouped in to "positive attitude", "negative attitude" and "neutral attitude" for the purpose of analysis. Once data was collected, SPSS 23 was used to analyze it. The results are reported as frequencies and percentages. Differences amongst group was demonstrated by Chi-squared test. P value of 0.05 was considered cut-off as statistically significant value.

\section{RESULTS}

Out of 396 respondents, most belonged to 3rd year (52.3\%) whereas others were in their final year (47.7\%). 69.7\% were completely unaware of the term superbugs and $79 \%$ were ignorant of the abbreviation AMR. $87.1 \%$ of respondents were able to differentiate between antibiotics and antimicrobials whereas according to $6.3 \%$ of dental students, there exists no difference between these two terms. 3.5\% had the idea of antibiotics as naturally occurring compounds whereas 3\% had no clue about this difference. In the present study, $37.1 \%$ of students responded not knowing about the number of deaths occurring worldwide as a consequence of infections from resistant bacteria whereas $27.3 \%$ reported 1 million, 22\% reported 35000 and $13.6 \%$ reported 10000 deaths. Table I depicts knowledge of students with regards to antibiotic resistance.

Table I - Crestal width and total horizontal dimension of the augmented ridge $(\mathrm{mm})$ of split-bone block and corticocancellous bock graft groups at different examination periods

\begin{tabular}{|c|c|c|}
\hline Statement / Survey item & $\begin{array}{l}\text { Sufficient } \\
\text { Knowledge }\end{array}$ & $\begin{array}{l}\text { Insufficient } \\
\text { Knowledge }\end{array}$ \\
\hline $\begin{array}{l}\text { Antibiotics kill both good and bad } \\
\text { bacteria }\end{array}$ & 288(72.7\%) & 108(27.3\%) \\
\hline Antibiotics kill viruses & $315(79.5 \%)$ & $81(20.5 \%)$ \\
\hline $\begin{array}{l}\text { Overuse of antibiotics makes them } \\
\text { ineffective }\end{array}$ & $339(85.6 \%)$ & $57(14.4 \%)$ \\
\hline Taking antibiotics often has side effects & $294(74.2 \%)$ & $102(25.8 \%)$ \\
\hline $\begin{array}{c}\text { Bacteria can become resistant to } \\
\text { antibiotics }\end{array}$ & $339(85.6 \%)$ & $57(14.4 \%)$ \\
\hline $\begin{array}{l}\text { Humans can become resistant to } \\
\text { antibiotics }\end{array}$ & $41(10.4 \%)$ & $355(89.6 \%)$ \\
\hline $\begin{array}{l}\text { Antibiotic resistant infections could } \\
\text { make medical procedures more dan- } \\
\text { gerous }\end{array}$ & $301(76 \%)$ & $95(24 \%)$ \\
\hline
\end{tabular}

Statistically significant difference was observed amongst year with respect to perception of antibiotics killing good and bad bacteria ( $\mathrm{p}=$ .05), human becoming resistant to antibiotics $(p=.01)$. Responses relating to attitude of students towards antibiotic use and resistance in shown in table II. 
Table II - Attitude of students towards antibiotic use and resistance

\begin{tabular}{|c|c|c|c|}
\hline Statement / Survey item & $\begin{array}{l}\text { Positive } \\
\text { Attitude }\end{array}$ & $\begin{array}{l}\text { Neutral } \\
\text { Attitude }\end{array}$ & $\begin{array}{l}\text { Negative } \\
\text { Attitude }\end{array}$ \\
\hline $\begin{array}{l}\text { Antibiotic resistance is one of the biggest } \\
\text { problems the world is facing }\end{array}$ & $351(88.6 \%)$ & $30(7.6 \%)$ & $15(3.8 \%)$ \\
\hline $\begin{array}{l}\text { Medical experts will solve the problems } \\
\text { of antibiotic resistance before it becomes } \\
\text { too serious }\end{array}$ & $270(68.2 \%)$ & $77(19.4 \%)$ & $49(12.4 \%)$ \\
\hline $\begin{array}{c}\text { People need to be accountable for using } \\
\text { antibiotic responsibly }\end{array}$ & $342(86.4 \%)$ & $43(10.9 \%)$ & $11(2.8 \%)$ \\
\hline $\begin{array}{l}\text { People like me can't do much to halt } \\
\text { resistance of bacteria }\end{array}$ & $243(61.4 \%)$ & $70(17.7 \%)$ & $83(21 \%)$ \\
\hline $\begin{array}{l}\text { Iam concerned about effect of antibiotic } \\
\text { resistance on me and my family }\end{array}$ & $331(83.6 \%)$ & $44(11.1 \%)$ & $21(5.3 \%)$ \\
\hline $\begin{array}{l}\text { Iam not at risk of getting an antibiotic } \\
\text { resistant infection if I take my antibiotic } \\
\text { correctly }\end{array}$ & $306(77.3 \%)$ & $48(12.1 \%)$ & $42(10.6 \%)$ \\
\hline $\begin{array}{l}\text { People should use antibiotics only when } \\
\text { they are prescribed by a doctor or nurse }\end{array}$ & $360(90.9 \%)$ & $22(5.6 \%)$ & $14(3.5 \%)$ \\
\hline $\begin{array}{l}\text { Farmers should give fewer antibiotics } \\
\text { to cattle }\end{array}$ & $311(78.5 \%)$ & $58(14.6 \%)$ & $27(6.8 \%)$ \\
\hline $\begin{array}{l}\text { Antibiotics must not be kept and used } \\
\text { later for other illness }\end{array}$ & $314(79.3 \%)$ & $56(14.1 \%)$ & $26(6.6 \%)$ \\
\hline $\begin{array}{l}\text { People should wash their hands regularly } \\
\text { with antibiotic hand wash }\end{array}$ & $273(68.9 \%)$ & $68(17.2 \%)$ & $55(13.9 \%)$ \\
\hline $\begin{array}{l}\text { Doctors should only prescribe antibiotics } \\
\text { when they are needed }\end{array}$ & $347(87.6 \%)$ & $21(5.3 \%)$ & $28(7.1 \%)$ \\
\hline
\end{tabular}

Statistically significant results were observed with regards to antibiotics being prescribed by doctor or nurse $(\mathrm{p}=.03)$, and doctor prescribing antibiotics only when needed $(\mathrm{p}=.01)$ between 3rd and 4th year students.

\section{DISCUSSION}

The study was conducted to assess the knowledge and attitude of dental students in clinical years regarding antibiotic resistance. Many studies have been done to estimate selfmedication amongst dentists and antibiotic prescription adherence of medical and dental students. However, this is the first study of such kind to be conducted in Pakistan.

As far as familiarity with the notion of antibiotic resistance was concerned, most of the respondents knew what was meant by this term. Conversely, they were unaware of alternative terms used to describe phenomenon of antibiotic resistance such as "Superbugs" and "AMR". This depicts lack of knowledge regarding the terminologies which are used to describe resistance of microbes. Data from several countries have painted a grim picture of dangers of antibiotic resistance, beginning with mounting mortality to being potentially powerless in stopping these infections in future [14]. Majority of respondents were oblivious of the mortality associated with antibiotic resistance. It is worthwhile to teach students about the burden of disease which can better help in understanding severity of the problem.

It was assumed that the students would be somehow knowledgeable about the impact of antibiotic resistance, which was fairly represented by respondents considering it a major public health threat. A study conducted in UAE also showed similar results where $84.5 \%$ of medical students knew what was meant by the concept of resistant bacteria [15].

Over-prescription of antibiotics is a dilemma; specially in conditions such as flu and common cold; that has left public health professionals perplexed [16]. It is one of the key cause of increasing antibiotic resistance globally, specially in low-setting countries where prescription is not regulated and antibiotics can be purchased over-the-counter. Most of the respondents in the study were knowledgeable about how overuse of antibiotics renders them ineffective in controlling infections. They were also adequately informed about the action of antibiotics on viruses and all bacteria; that is; those that cause infection and those part of normal flora. Similar results were seen in another study where majority of respondents knew that antibiotics do not have any effect on viral infections [17]. his possibly can be attributed to the fact that medical and dental students are taught about pharmacokinetics in their earlier years so that they are informed about effects of different medications on different microbes.

The respondents were very well aware of the fact that bacteria can become resistant to action of antibiotics. On the contrary, majority thought that humans have the ability to develop resistance against antibiotics, which is untrue. 
Such notions develop when sufficient information is not imparted to students in academic institutions, pointing to lack of curriculum revision. Another study also demonstrated that most students gained knowledge of antibiotic use and prescription from their teachers [8]. Hence, it is essential that students should be educated about mechanism of action of antibiotic resistance. Overall, most of them had satisfactory knowledge regarding the concepts of antibiotic resistance and what could potentially cause it.

A considerable percentage of antibiotics have been known to be prescribed to patients in primary care [16]. However, after introducing interventions; specially aimed at physicians; marked reduction in antibiotic prescription was observed [16]. This demonstrates how revision of prescription practices and dissemination of this knowledge to practitioners can potentially reduce incorrect antibiotic prescription. This also cements the fact that health practitioners are more than capable of reducing the spread of antibiotic resistant infections. Since some respondents did not believe that they could somehow control the phenomenon of antibiotic resistance, this idea needs to be dismantled. To overcome this issue, students should be taught about the concept of antibiotic stewardship and evidence-based prescription practices, then only it will be possible to curb the danger of illnesses due to antibiotic resistance. Majority of respondents agreed that antibiotics should only be used when they are prescribed by a health professional. Subsequently, 92.3\% students in another study carried out in Nepal consulted doctor for a prescription [18].

Handwashing has been widely circulated as an efficient preventive method of reducing bacterial and viral infections. This will consequently diminish intake of antibiotic hence, reducing antibiotic resistance. Most respondents thought that people should wash their hands regularly with antibiotic hand wash. This stands true for health professionals dealing with patients on regular basis however, the higher efficacy of antibiotic hand wash over normal hand wash/soap has not been demonstrated and not recommended for use among general public [19].

\section{CONCLUSION}

Although students were generally aware of antibiotic resistance and had positive attitude however, some inconsistencies were observed in knowledge. This will need to be addressed through incorporating evidence-based guidelines in curriculum and gaining information on their practices in their internship year where they can individually treat and carry out prescriptions.

\section{Acknowledgments}

\section{Funding} this study

The authors did not receive any funding for

\section{Conflict of interest}

The authors declare no proprietary, financial, or other personal interest of any nature or kind in any product, service, and/or company that is presented in this article.

\section{Regulatory Statement}

This study was conducted in accordance with all the provisions of the local human subject's oversight committee guidelines and policies of: University of Lahore. The approval code for this study is: UCD/ERCA/19/02ab

\section{REFERENCES}

1. World Health Organization [Internet]. Antibiotic resistance [cited 2021 Mar 12]. Avaliable from: https://www.who.int/news-room/fact-sheets/detail/ antibiotic-resistance

2. Certers for Disease Control and Prevention [Internet]. About antibiotic resistance [cited 2021Mar 12]. Avaliable from: https://www.cdc.gov/ drugresistance/abouthtml

3. Cassini A, Högberg LD, Plachouras D, Quattrocchi A, Hoxha A, Simonsen GS, et. al. Attributable deaths and disability-adjusted life-years caused by infections with antibiotic-resistant bacteria in the EU and the European Economic Area in 2015: a population-level modelling analysis. Lancet Infect Dis. 2018;19(1):56-66.

4. Shaikh S. China, India lead rise in global antibiotic consumption. Sci Dev Net [Internet]. 2028 Apr 18 [cited 2021 Mar 12]. Avaliable from: https://www. scidev.net/asia-pacific/news/china-india-lead-rise-in-global-antibioticconsumption/ 
5. Philip K, Teoh WY, Muniandy S, Yaakob H. Pathogenic bacteria predominate in the oral cavity of malaysian subjects. J Biol Sci. 2009;9(5):438-44.

6. Feres M, Retamal-Valdes B, Mestnik MJ, Figueiredo LC, Faveri M, Duarte PM, et al. The ideal time of systemic metronidazole and amoxicillin administration in the treatment of severe periodontitis: study protocol for a randomized controlled trial. Trials. 2018;19(1):201

7. AboAlSamh A, Alhussain A, Alanazi N, Alahmari R, Shaheen N, Adlan A. Dental students' knowledge and attitudes towards antibiotic prescribing guidelines in Riyadh, Saudi Arabia. Pharmacy. 2018;6(2):42.

8. Mahmood A, Tahir MW, Abid A, Saad Ullah M, Sajiji M. Knowledge of drug prescription in dental students of Punjab Pakistan. Pak J Med Sci. 2018;12(1):232-8.

9. Wong YC, Mohan M, Pau A. Dental students' compliance with antibiotic prescribing guidelines for dental infections in children. J Ind Soc Ped Prev Dent. 2016;34(4):348-53.

10. British Dental Association [Internet]. Antibiotic resistance in dentistry [cited 2021 Mar 12]. Avaliable from: https://bda.org/amr

11. Ventola CL. The antibiotic resistance crisis: part 1 causes and threats. Pharm Ther. 2015;40(4):277-83.

12. Chaintarli K, Ingle SM, Bhattacharya A, Ashiru-Oredope D, Oliver I, Gobin M. Impact of a United Kingdom wide campaign to tackle antimicrobial resistance on self-reported knowledge and behaviour change. BMC Public Health. 2016;16(1):1-9.
13. World Health Organization. Antibiotic resistance: multi-country public awareness survey. Genebra: WHO;2015.

14. Aslam B, Wang W, Arshad MI, Khurshid M, Muzammil S, Rasool MH, et al. Antibiotic resistance: a rundown of a global crisis. Infect Drug Resist 2018;11:1645-58.

15. Jairoun A, Hassan N, Ali A, Jairoun O, Shahwan M. Knowledge, attitude and practice of antibiotic use among university students: a cross-sectional study in UAE. BMC Public Health. 2019;19:518.

16. Shallcross LJ, Davies DS. Antibiotic overuse: a key driver of antimicrobial resistance. Br J Gen Pract. 2014;64(629):604-5.

17. Jorak A, Keihanian F, Saeidinia A, Heidarzadeh A, Saeidinia F. A cross sectional study on knowledge, attitude and practice of medical students toward antibiotic resistance and its prescription, Iran. Adv Environ Biol. 2014;8(17):675-81.

18. Shah P, Shrestha R, Mao Z, Chen Y, Chen Y, Koju P, et al. Knowledge, attitude, and practice associated with antibiotic use among university students: a survey in Nepal. Int J Environ Res Public Health. 2019;16(20):3996.

19. Larson E, Aiello A, Lee LV, Della-Latta P,Gomez-Duarte C, Lin S. Short-and long-term effects of handwashing with antimicrobial or plain soap in the community. J Community Health. 2003;28(2):139-50.

\section{Eisha Imran}

(Corresponding address)

Department of Dental Materials, Islamic International Dental College, Riphah International University, Islamabad, Pakistan. 